\title{
Residue addition frequency influences respiration, microbial biomass and nutrient availability in soil amended with high and low $\mathrm{C} / \mathrm{N}$ residue
}

\author{
Bo Zheng, Petra Marschner \\ School of Agriculture, Food and Wine, The University of Adelaide, South Australia, 5005, Australia. \\ Corresponding author: petra.marschner@adelaide.edu.au
}

\begin{abstract}
In previous studies, we showed that the $\mathrm{C} / \mathrm{N}$ ratio of the first residue added influences soil respiration, microbial biomass and nutrient availability after the second residue addition which we refer to as legacy effect. The aim of the study was to investigate the effect of residue addition frequency on microbial activity and nutrient availability, and the legacy effect.

In Part $\mathrm{A}$, the effect of high $\mathrm{C} / \mathrm{N}$ residue $(\mathrm{H})$ addition frequency in the first 16 days $(\mathrm{d})$ was studied by adding $\mathrm{H}$ to soil once (d0), twice $(\mathrm{d} 0,8)$ or four times $(\mathrm{d} 0,4,8,12)$ followed by $10 \mathrm{~g} \mathrm{~kg}^{-1}$ low C/N residue (L) on day 16. The influence of $\mathrm{L}$ addition rate was assessed in Part $\mathrm{B}$ by adding $\mathrm{H}$ once on day 0 followed by $\mathrm{L}$ added once (d16), twice $(\mathrm{d} 16,24)$ or four times $(\mathrm{d} 16,20,24,24,28)$. Cumulative respiration, microbial biomass $\mathrm{C}, \mathrm{N}$ and $\mathrm{P}, \mathrm{N}$ and $\mathrm{P}$ availability from $\mathrm{d} 0$ to $\mathrm{d} 15$ were higher with $\mathrm{L}$ than $\mathrm{H}$. Particularly with $\mathrm{L}$, cumulative respiration, microbial biomass and nutrient availability compared to single addition were lower on $\mathrm{d} 7 \mathrm{with}$ residue added twice or four times, but higher on d15. In Part A, H added twice or four times from d0 to d15 compared to a single $\mathrm{H}$ addition followed by a single $\mathrm{L}$ addition on $\mathrm{d} 16$ increased cumulative respiration, microbial nutrient uptake and reduced $\mathrm{N}$ and $\mathrm{P}$ availability on $\mathrm{d} 23$, but had no effect on $\mathrm{d} 32$. In Part $\mathrm{B}$, frequent $\mathrm{L}$ addition after d16 enhanced microbial nutrient uptake on $\mathrm{d} 23$ but reducing nutrient availability compared to single L addition. It can be concluded that residue addition frequency strongly influences soil respiration, microbial biomass and nutrient availability after addition of low $\mathrm{C} / \mathrm{N}$ residue.
\end{abstract}

Keywords: Amendment frequency, microbial biomass, nutrient availability, residue $\mathrm{C} / \mathrm{N}$ ratio, soil respiration 


\section{Introduction}

Plant residue decomposition rate and nutrient dynamics are influenced by the chemical composition of organic amendments. For example, plant residues with high $\mathrm{C} / \mathrm{N}$ ratio will cause net $\mathrm{N}$ immobilisation whereas low $\mathrm{C} / \mathrm{N}$ ratio plant residue induce net $\mathrm{N}$ mineralisation and have higher decomposition rates than high $\mathrm{C} / \mathrm{N}$ residues (Tian et al., 1992; Vanlauwe et al., 1996; Hadas et al., 2004; Scotti et al., 2015). Amendment $\mathrm{C} / \mathrm{N}$ ratio also influences microbial community composition, particularly fungal and bacterial abundance and growth. High $\mathrm{C} / \mathrm{N}$ amendments have been shown to stimulate fungi whereas bacteria are stimulated by addition of low $\mathrm{C} / \mathrm{N}$ organic materials (e.g., Rousk and Bååth, 2007; Barreiro et al. 2016). Most studies on the effect of organic amendments on soil properties have been carried out with single additions. Only a few studies investigated the effect of repeated soil amendments on soil respiration and microbial biomass. Cavalli et al. (2014) showed that repeated slurry application increased soil respiration compared to a single addition and increased proportion of $\mathrm{CO}_{2}$ derived from slurry while reducing the proportion of $\mathrm{CO}_{2}$ from SOC. De Nobili et al. (2001) demonstrated that repeated addition of trace amounts of glucose increased $\mathrm{CO}_{2}$ release compared to a single addition beyond the amount of $\mathrm{C}$ added with glucose. These authors suggested that trace amounts of substrate stimulate turnover of microbial biomass because biomass $\mathrm{C}$ was not increased by glucose addition. Elmajdoub and Marschner (2015) found that repeated legume residue addition reduced the negative effect of salinity on soil respiration compared to a single addition. In the study by Duong et al. (2009) the same amount of high $\mathrm{C} / \mathrm{N}$ residue was applied once, four, eight or 16 times (added every 16, 8 or 4 days, respectively) over a period of 60 days. They found that compared to a single addition, repeated addition increased cumulative respiration per $\mathrm{g} \mathrm{C}$ added and that this stimulation increased with addition frequency. In their study, addition frequency did not influence microbial biomass $\mathrm{C}$ or available $\mathrm{N}$.

Studies of our group showed that the $\mathrm{C} / \mathrm{N}$ ratio of the previous organic amendment influences soil respiration, microbial biomass and nutrient availability after the second residue addition (Marschner et al., 2015; Nguyen et al., 2016a; Nguyen et al., 2016b). We termed this legacy effect of the previous addition. For example, cumulative respiration and nutrient availability were greater when high $\mathrm{C} / \mathrm{N}$ residue was added after low $\mathrm{C} / \mathrm{N}$ compared to high $\mathrm{C} / \mathrm{N}$ residue alone whereas previous addition of high $\mathrm{C} / \mathrm{N}$ residue reduced $\mathrm{N}$ availability compared to low $\mathrm{C} / \mathrm{N}$ alone. The extent of the legacy effect was influenced by the time between the two residue additions and soil water content during this time (Nguyen et al., 2016a; Nguyen et al., 2016b). Recently we showed that the legacy effect decreases with rate of the first residue (Zheng and Marschner 2016), indicating that the amount of the first residue in the soil when the second residue is added influences the extent of the legacy effect. The legacy effect could also be influenced by the frequency at which the first residue is added through its effect on decomposition rate and microbial activity. With repeated addition and thus supply of easily decomposable compounds, a greater proportion of the microbial biomass remains active than with a single addition which could influence nutrient availability after the second residue type is added.

The aim of the present study was to investigate the effect of residue addition frequency on soil respiration, microbial biomass and nutrient availability after the first and the second residue addition. We used high $\mathrm{C} / \mathrm{N}$ followed by low $\mathrm{C} / \mathrm{N}$ residue because in our previous studies (Marschner et al. 2015, Nguyen et al. 
2016), the legacy effect was greatest in this treatment. High $\mathrm{C} / \mathrm{N}$ residue was added once, twice or four times over the first 16 days followed by a single $\mathrm{L}$ addition. Or $\mathrm{H} \mathrm{C} / \mathrm{N}$ residue was added once (day 0 ), followed by $\mathrm{L}$ added once, twice or four times over the following 16 days. The hypotheses were (i) frequent residue addition compared to a single addition will result in smaller residue effect on respiration, microbial biomass and nutrient availability initially, but later these parameters will be higher because of the greater availability of easily decomposable compounds; (ii) the legacy effect of the previous residue will be greater when it is added frequently compared to a single addition, and (iii) the legacy effect of a previous single addition will be be smaller when the following residue is added frequently compared to a single addition.

\section{Material and Methods}

The soil was collected from 0 to $10 \mathrm{~cm}$ depth at Waite Campus, The University of Adelaide, South Australia (Longitude $138^{\circ} 38^{\prime} \mathrm{E}$, Latitude $35^{\circ} 6^{\prime} \mathrm{S}$ ) that had been under permanent pasture over 80 years. This area is in a semi-arid region and has a Mediterranean climate with cool, wet winters and hot, dry summers. The soil is classified as Red-brown Earth in Australian Classification (Isbell, 2002) and as Rhodoxeralf in US Soil Taxonomy (Chittleborough and Oades, 1979). At the sampling site, the soil was collected at several randomly chosen locations and pooled to one composite sample. The soil was dried at $40{ }^{\circ} \mathrm{C}$ and sieved to $<2 \mathrm{~mm}$. It has the following properties: $22 \%$ sand, $60 \%$ silt, $18 \%$ clay, maximum water capacity (WHC) $371 \mathrm{~g} \mathrm{~kg}^{-1}, \mathrm{pH}(1: 5)$ 5.6, EC (1:5) $0.1 \mathrm{dS} \mathrm{m}^{-1}$, total organic $\mathrm{C} 17 \mathrm{~g} \mathrm{~kg}^{-1}$, total organic $\mathrm{N} 1.5 \mathrm{~g} \mathrm{~kg}^{-1}$, bulk density $1.3 \mathrm{~g} \mathrm{~cm}^{-1}$, available P $10 \mathrm{mg} \mathrm{P} \mathrm{kg}^{-1}$ and available $\mathrm{N} 15 \mathrm{mg} \mathrm{N} \mathrm{kg}^{-1}$.

Two plant residues with distinct properties were used in this experiment (Table 1): low $\mathrm{C} / \mathrm{N}$ young faba bean (L, Vicia faba L.) and high $\mathrm{C} / \mathrm{N}$ mature wheat shoots
$(\mathrm{H}$, Triticum aestivum L.). The residues were dried at $40{ }^{\circ} \mathrm{C}$ and sieved to particle size 0.25 to $1 \mathrm{~mm}$.

\subsection{Experimental design}

Before the experiment, the soil was pre-incubated at $50 \%$ of WHC (water holding capacity) for ten days in the dark at $24{ }^{\circ} \mathrm{C}$ to activate the soil microbes and allow soil respiration to become stable after rewetting. In our previous study with the same soil (Marschner et al. 2015), respiration was maximal at this water content. The experiment was divided into two parts which were conducted in parallel. One treatment $(\mathrm{H}$ added once followed by $\mathrm{L}$ added one) was included in both parts for easier assessment of the legacy effect (Table 2). The effect of addition frequency of $\mathrm{H}$ in the first period was investigated in Part A. In the first 15 days, $\mathrm{H}$ was added once (day 0 at $10 \mathrm{~g} \mathrm{~kg}^{-1}$, $\mathrm{H} 1$ ), twice (days 0 and 8 at $5 \mathrm{~g} \mathrm{~kg}^{-1}, \mathrm{H} 2$ ) or four times (days $0,4,8$ and 12 at $2.5 \mathrm{~g} \mathrm{~kg}^{-1}, \mathrm{H} 4$ ). Then $\mathrm{L}$ was added once on day 16, giving treatments H1-L1, H2-L1 and H4-L1. In Part B, the effect of addition frequency of $\mathrm{L}$ from day 16 was studied. There were three treatments: $\mathrm{H}$ was added once on day 0 at 10 $\mathrm{g} \mathrm{kg}^{-1}$ which was followed by $\mathrm{L}$ added once (day 16 at $10 \mathrm{~g} \mathrm{~kg}^{-1}, \mathrm{H} 1-\mathrm{L} 1$ ), twice (days 16 and 24 at $5 \mathrm{~g}$ $\mathrm{kg}^{-1}, \mathrm{H} 1-\mathrm{L} 2$ ) or four times (days 16, 20, 24 and 28 at $\left.2.5 \mathrm{~g} \mathrm{~kg}^{-1}, \mathrm{H} 1-\mathrm{L} 4\right)$. There were four replicates per treatment and sampling time. Unamended controls were not included because in previous studies with the same soil, soil respiration, microbial biomass and nutrient availability were very low.

All treatments were mixed in a similar manner every four days whether residues were added or not. After each residue addition, $30 \mathrm{~g}$ dry soil equivalent was filled into PVC cores with $1.85 \mathrm{~cm}$ radius, $5 \mathrm{~cm}$ height and a nylon mesh base $(7.5 \mu \mathrm{m}$, Australian Filter Specialist) and packed to a bulk density of $1.3 \mathrm{~g} \mathrm{~cm}^{-1}$ by adjusting the height of the soils in the cores. 
Table 1. Properties of low (young faba bean shoots) and high $\mathrm{C} / \mathrm{N}$ (mature wheat straw) residues $(\mathrm{n}=4)$.

\begin{tabular}{lll}
\hline Properties & Low C/N & High C/N \\
\hline Total organic carbon $\left(\mathrm{g} \mathrm{kg}^{-1}\right)$ & $375 \pm 30$ & $405 \pm 5$ \\
Total N & $20.3 \pm 1$ & $5.5 \pm 0.6$ \\
Total P & $3.9 \pm 0.2$ & $0.3 \pm 0.0$ \\
C/N ratio & $19 \pm 3$ & $73 \pm 9$ \\
C/P ratio & $99 \pm 15$ & $1185 \pm 25$ \\
Water extractable C $\left(\mathrm{g} \mathrm{kg}^{-1}\right)$ & 92 & 54 \\
Available N $\left(\mathrm{mg} \mathrm{kg}^{-1}\right)$ & 487 & 87 \\
Available P $\left(\mathrm{mg} \mathrm{kg}^{-1}\right)$ & 247 & 30 \\
\hline
\end{tabular}

Table 2. Experimental design with treatment names and residue type (high or low $\mathrm{C} / \mathrm{N})$ and addition rates $(2.5,5$ or $10 \mathrm{~g} \mathrm{~kg}^{-1}$ ) during the experiment.

\begin{tabular}{|c|c|c|c|c|c|c|c|c|}
\hline \multirow[t]{2}{*}{ Treatment } & \multicolumn{8}{|c|}{$\mathrm{C} / \mathrm{N}$ ratio and rate $\left(\mathrm{g} \mathrm{kg}^{-1}\right)$ of residue added } \\
\hline & 0 & 4 & 8 & 12 & 16 & 20 & 24 & 28 \\
\hline \multicolumn{9}{|l|}{ PartA } \\
\hline H1-L1 & $\mathrm{H} 10$ & & & & L10 & & & \\
\hline H2-L1 & $\mathrm{H} 5$ & & H5 & & L10 & & & \\
\hline H4-L1 & $\mathrm{H} 2.5$ & $\mathrm{H} 2.5$ & $\mathrm{H} 2.5$ & $\mathrm{H} 2.5$ & L10 & & & \\
\hline \multicolumn{9}{|l|}{ PartB } \\
\hline H1-L1 & $\mathrm{H} 10$ & & & & L10 & & & \\
\hline H1-L2 & $\mathrm{H} 10$ & & & & L5 & & L5 & \\
\hline H1-L4 & $\mathrm{H} 10$ & & & & L2.5 & L2.5 & L2.5 & L2.5 \\
\hline
\end{tabular}

The cores were placed individually into $1 \mathrm{~L}$ jars with gas-tight lids equipped with septa to allow quantification of the headspace $\mathrm{CO}_{2}$ concentration as described below. The jars were incubated in the dark at 23-25 ${ }^{\circ} \mathrm{C}$. Soil moisture was maintained at $50 \%$ of WHC throughout the experiment by checking the water content every few days by weight and adding reverse osmosis (RO) water if necessary. Soil respiration was measured daily. Cores were destructively sampled on days 0 (2 hours after residue addition, only available $\mathrm{N}$ and $\mathrm{P}$ ), day 7, day 15 (before $\mathrm{L}$ addition), day 23 (after $\mathrm{L}$ addition on day 16), and day 32 for analysis of available $\mathrm{N}$ and $\mathrm{P}$, microbial biomass $\mathrm{C}, \mathrm{N}$ and $\mathrm{P}$. There were four replicates per residue treatment and sampling time. Microbial biomass $\mathrm{C}, \mathrm{N}$ and $\mathrm{P}$ were not determined on day 0 to avoid overestimation of microbial biomass by $\mathrm{C}, \mathrm{N}$ and $\mathrm{P}$ released by chloroform from freshly added residues.

\subsection{Analyses}

Soil texture was determined by the hydrometer method (Gee and Or, 2002). Soil maximum water holding capacity was measured using a sintered glass funnel connected to a $1 \mathrm{~m}$ water column (matric potential $=-10 \mathrm{kPa})($ Wilke, 2005). Soil $\mathrm{pH}$ was determined in a 1:5 (w/v) soil to RO water ratio after one $\mathrm{h}$ endover-end shaking (Rayment and Higginson, 1992). 
Total organic $\mathrm{C}$ of soil and residues was determined by wet oxidation and $\mathrm{K}_{2} \mathrm{Cr}_{2} \mathrm{O}_{7}$ and $\mathrm{H}_{2} \mathrm{SO}_{4}$ oxidation by titration with acidified $\left(\mathrm{NH}_{4}\right)_{2} \mathrm{Fe}\left(\mathrm{SO}_{4}\right)_{2} \cdot 6 \mathrm{H}_{2} \mathrm{O}$ (Walkley and Black, 1934). Soil and residue total $\mathrm{N}$ content were measured by the Kjeldahl method. Total P of plant residues and soil was determined after acid digestion by the phosphovanadomolybdate method (Hanson, 1950). Water extractable organic C (WEOC) was determined by shaking $1 \mathrm{~g}$ residue with $30 \mathrm{ml}$ reverse osmosis water for $1 \mathrm{~h}$. The extract was centrifuged at $1509 \times \mathrm{g}$ for 10 min and filtered through a Whatman \#42 filter paper. The WEOC concentration of the extract was determined after $\mathrm{K}_{2} \mathrm{Cr}_{2} \mathrm{O}_{7}$ and $\mathrm{H}_{2} \mathrm{SO}_{4}$ oxidation by titration with acidified $\left(\mathrm{NH}_{4}\right)_{2} \mathrm{Fe}\left(\mathrm{SO}_{4}\right)_{2} \cdot 6 \mathrm{H}_{2} \mathrm{O}$ (Anderson and Ingram, 1993). Solutions with different sucrose concentrations $\left(0.01^{-1} \mathrm{mg} \mathrm{C} \mathrm{ml}^{-1}\right)$ were used as standards. Soil respiration was determined daily by measuring the $\mathrm{CO}_{2}$ concentration in the headspace of the jars using a Servomex 1450 infrared gas analyser (Servomex, UK) as described in (Setia et al., 2011). After each measurement $\left(T_{1}\right)$, the jars were vented to refresh the headspace using a fan and then resealed followed by determination of the $\mathrm{CO}_{2}$ concentration $\left(\mathrm{T}_{0}\right)$. The $\mathrm{CO}_{2}$ evolved during a given interval was calculated as the difference in $\mathrm{CO}_{2}$ concentration between $\mathrm{T}_{1}$ and $\mathrm{T}_{0}$. Linear regression-based on the injection of known amounts of $\mathrm{CO}_{2}$ in jars of similar size was used to define the relationship between $\mathrm{CO}_{2}$ concentration and detector reading. Cumulative respiration was calculated as the sum of respiration rates [in $\mathrm{mg} \mathrm{CO}_{2}-\mathrm{C}$ (g soil and day) ${ }^{-1}$ ] for different intervals: 8, 16 and 32 days.

Soil microbial biomass $\mathrm{C}(\mathrm{MBC})$ and $\mathrm{N}(\mathrm{MBN})$ were determined by chloroform fumigation-extraction (Vance et al., 1987). Soil samples were exposed to 48-h chloroform fumigation and followed by shaking with $0.5 \mathrm{M} \mathrm{K}_{2} \mathrm{SO}_{4}$ at a 1:4 soil: solution ratio. Extracts were filtered through Whatman \#42 filter paper. The organic $\mathrm{C}$ concentration in the extract of fumigated and non-fumigated soils was determined by adding
$0.0667 \mathrm{M} \mathrm{K}_{2} \mathrm{Cr}_{2} \mathrm{O}_{7}$ and concentrated $\mathrm{H}_{2} \mathrm{SO}_{4}$. The remaining $\mathrm{K}_{2} \mathrm{Cr}_{2} \mathrm{O}_{7}$ was titrated with $0.033 \mathrm{M}$ acidified $\left(\mathrm{NH}_{4}\right)_{2} \mathrm{Fe}\left(\mathrm{SO}_{4}\right)_{2} \cdot 6 \mathrm{H}_{2} \mathrm{O}$ (Anderson and Ingram, 1993). The difference in $\mathrm{C}$ concentration between fumigated and non-fumigated soil was multiplied by 2.64 to calculate MBC (Vance et al., 1987). For MBN, the ammonium concentration of the $\mathrm{K}_{2} \mathrm{SO}_{4}$ extract was determined after Willis et al. (1996). To calculate MBN, the difference between fumigated and non-fumigated soil was multiplied by 1.75 (Moore et al., 2000).

Available N (ammonium and nitrate) concentration in soil and residues was measured after $1 \mathrm{~h}$ end-over-end shaker with $2 \mathrm{M} \mathrm{KCl}$ at 1:5 soil extractant ratio. Ammonium-N was determined after Willis et al. (1996). Nitrate-N was determined as described in Cavagnaro et al. (2006). Soil and residues available $\mathrm{P}$ was extracted by the anion exchange resin method (Kouno et al., 1995). This method was also used to determine microbial biomass $\mathrm{P}$ (MBP) which was calculated as the difference between available $\mathrm{P}$ and $\mathrm{P}$ extracted with hexanol. The P concentration was determined colorimetrically (Murphy and Riley, 1962). The recovery of a P spike in this soil was 98\% (Butterly et al., 2010). Therefore no correction factor was used.

\subsection{Statistical analysis}

The data was normally distributed. The data of parameters that were determined several times were analysed by one way repeated measures ANOVA with treatments as fixed factor. It showed that the treatment $x$ time interaction was significant. Then the data for each sampling date was analysed separately by one-way ANOVA followed by Tukey's multiple comparison tests at $95 \%$ confidence interval to determine significant differences among treatments. Statistical analyses were carried out in Genstat 15th edition (VSN Int. Ltd., UK). 


\section{Results}

\subsection{H added once, twice or four times in first 16 days} followed by single L addition on 116 (Part A)

Respiration rates on d1 were higher in H1-L1 than H2-L1 and H4-L1 (Figure 1a). Repeated H addition in H2-L1 and H4-L1 transiently increased respiration rate. Addition of $\mathrm{L}$ to $\mathrm{H}-\mathrm{L}$ treatments on $\mathrm{d} 16$ resulted in an up to 10-fold increase in respiration rate on d17. Respiration rate on $\mathrm{d} 17$ was higher when $\mathrm{H}$ had been added two or four times (H2-L1, H4-L1) than with a single $\mathrm{H}$ addition (H1-L1).
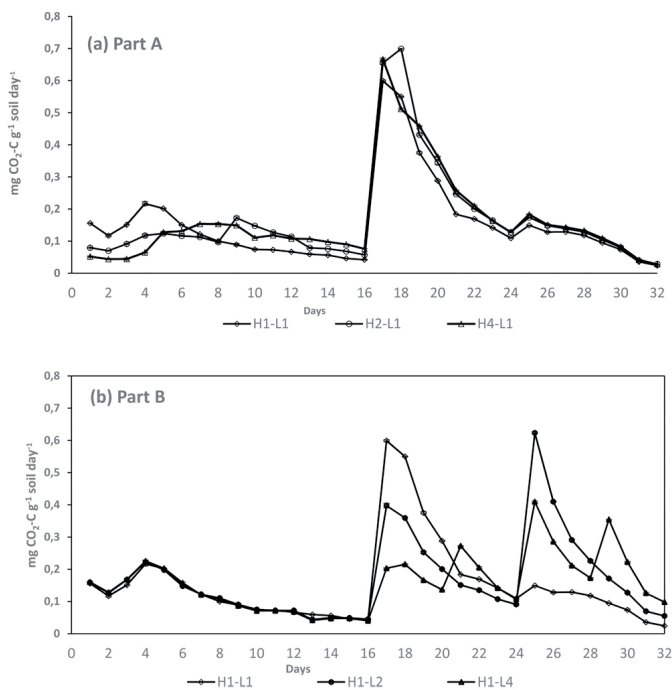

Figure 1. Respiration rate in soil amended with high $\mathrm{C} / \mathrm{N}(\mathrm{H})$ and then low $\mathrm{C} / \mathrm{N}$ residue. Part $\mathrm{A}$ (a) different frequencies of $\mathrm{H}$ in first 15 days followed by single $\mathrm{L}$ addition, and Part $\mathrm{B}$ (b) single $\mathrm{H}$ addition in first 15 days followed by different frequencies of $\mathrm{L}(\mathrm{n}=4)$. For treatment structure, see Table 2.

Among treatments, cumulative respiration in the first 16 days was about $40 \%$ higher in H1-L1 than H2-L1 and H4-L1 (Figure 2a), but the reverse was true in the period from $\mathrm{d} 8$ to $\mathrm{d} 15$. Compared to the first 8 days, cumulative respiration from $\mathrm{d} 8$ to $\mathrm{d} 15$ was lower in H1-L1, but abut 20\% higher with H2-L1 and H4-L1. Cumulative respiration per g $\mathrm{C}$ added was about $30 \%$ lower in H1-L1 than in H2-L1 and H4-L1 (data not shown). Cumulative respiration from d16 to d23 (after $\mathrm{L}$ addition on d16) was three to five-fold higher than in the previous 8 -day period. It was about $15 \%$ higher in H2-L1 and H4-L1 than H1-L1. Cumulative respiration from $\mathrm{d} 24$ to $\mathrm{d} 32$ was more than $50 \%$ lower than from d16 to d23, but it was still lower in H1-L1 than H2-L1 and H4-L1.
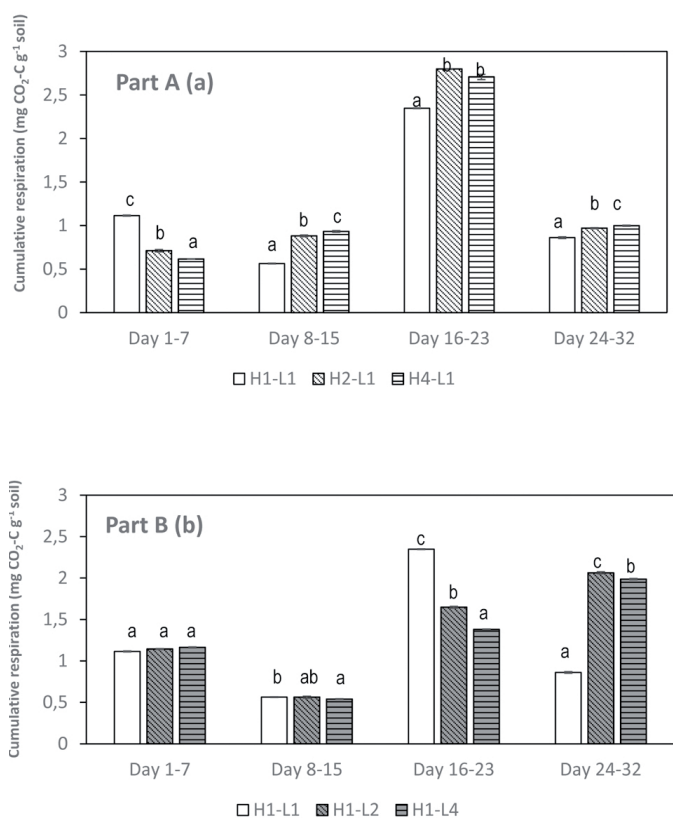

Figure 2. Cumulative respiration per g soil in eight-day intervals (days 1-7; 8-15; 16-23 and 24-32) in soil amended with high $\mathrm{C} / \mathrm{N}(\mathrm{H})$ and then low $\mathrm{C} / \mathrm{N}$ residue. Part $\mathrm{A}$ (a) different frequencies of $\mathrm{H}$ in first 15 days followed by single addition, and Part B (b) single $\mathrm{H}$ addition in first 15 days followed by different frequencies of $\mathrm{L}(\mathrm{n}=4)$. For each sampling date, different letters indicate significant differences $(\mathrm{P} \leq 0.05)$. For treatment structure, see Table 2. 
On d7, MBC was about 40\% higher in $\mathrm{H} 1-\mathrm{L} 1$ and $\mathrm{H} 2-$ L1 than H4-L1 (Figure 3a). In all treatments, MBC was lower on $\mathrm{d} 15$ than $\mathrm{d} 7$, with no difference among $\mathrm{H}$ treatments. Addition of L on d16 in H-L treatments
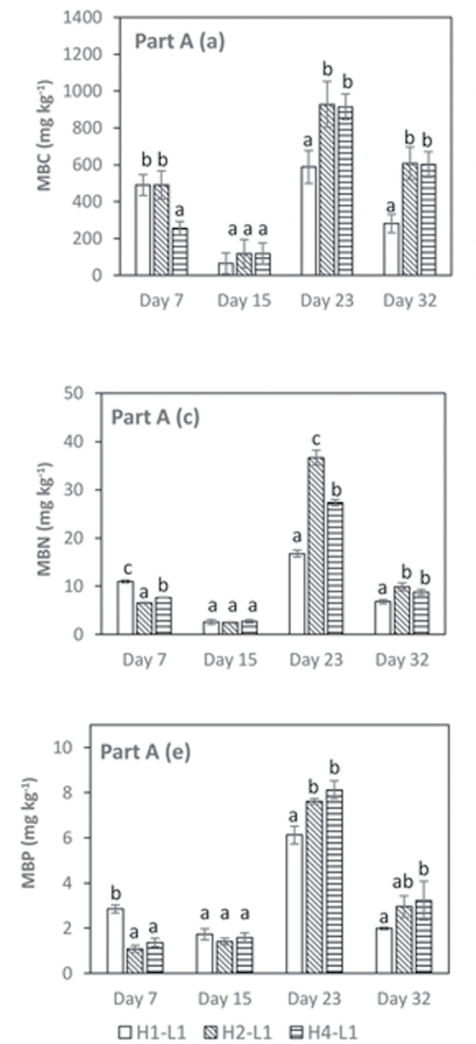

resulted in a six to eight-fold higher $\mathrm{MBC}$ on $\mathrm{d} 23$ than d15, but MBC decreased by about $40 \%$ from $\mathrm{d} 23$ to d32. On both $\mathrm{d} 23$ and $\mathrm{d} 32, \mathrm{MBC}$ was about $40 \%$ higher in H2-L1 and H4-L1 than in H1-L1.
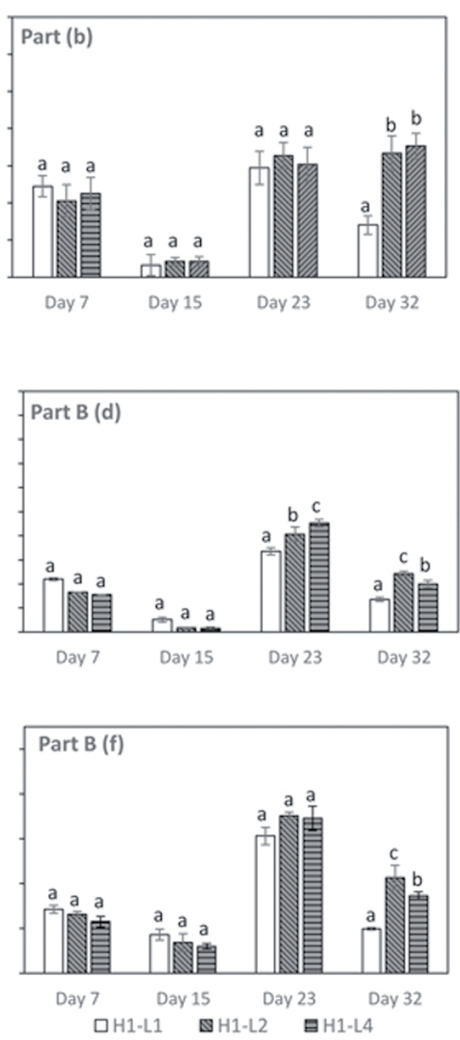

Figure 3. Microbial biomass $\mathrm{C}(\mathrm{a}, \mathrm{b}), \mathrm{N}(\mathrm{c}, \mathrm{d})$ and $\mathrm{P}(\mathrm{e}, \mathrm{f})$ concentration on days $0,7,15,23,32$ in soil amended with high $\mathrm{C} / \mathrm{N}$ $(\mathrm{H})$ and then low $\mathrm{C} / \mathrm{N}$ residue. Part $\mathrm{A}(\mathrm{a}, \mathrm{c}, \mathrm{e})$ different frequencies of $\mathrm{H}$ in first 15 days followed by single addition, and Part $\mathrm{B}$ (b, d, f) single $\mathrm{H}$ addition in first 15 days followed by different frequencies of $\mathrm{L}(\mathrm{n}=4)$. For each sampling date, different letters significant differences $(\mathrm{P} \leq 0.05)$. For treatment structure, see Table 2.

Microbial biomass $\mathrm{N}$ and $\mathrm{P}$ had similar differences among treatments and over time, but the differences were less pronounced with MBP than MBN. On d7, MBN and MBP were highest in H1-L1, but there were no differences among treatments on d15 (Figure $3 \mathrm{c}$, e). From d15 to d23, MBN and MBP increased five to ten-fold and four fold, respectively, with a greater increase in H2-L1 and H4-L1 than H1-L1. On d23 compared MBN and MBP were lowest in H1-L1. From d 23 to $\mathrm{d} 32, \mathrm{MBN}$ and MBP in all treatments, but were still about $20 \%$ higher in H2-L1 and H4-L2 than H1-L1. 
Available $\mathrm{N}$ and $\mathrm{P}$ on $\mathrm{d} 0, \mathrm{~d} 7$ and $\mathrm{d} 15$ differed little among treatments except for temporarily lower available $\mathrm{N}$ and $\mathrm{P}$ in H1-L1 on days 15 and 7, respectively (Figure $4 \mathrm{a}, \mathrm{c}$ ). From d15 to d23, available N increased six-fold in H1-L1, but only two-fold in H2-L1 and did not change in H4-L1. On d23, available $\mathrm{N}$ was about two-fold higher in H1-L1 and H2-L1 than H4L1. Available $\mathrm{N}$ did not change from $\mathrm{d} 23$ to $\mathrm{d} 32$ in
H1-L1 and H2-L1, but increased nearly three-fold in H4-L1.

Available P increased about two-fold from d15 to d23; on $\mathrm{d} 23$, it was about $15 \%$ higher in H1-L1 and H2-L1 than H4-L1. Available P did not change from d23 to d32 in H1-L1 and H2-L1 but increased by $20 \%$ in H4-L1. The treatments differed little in available $\mathrm{P}$ on $\mathrm{d} 32$.
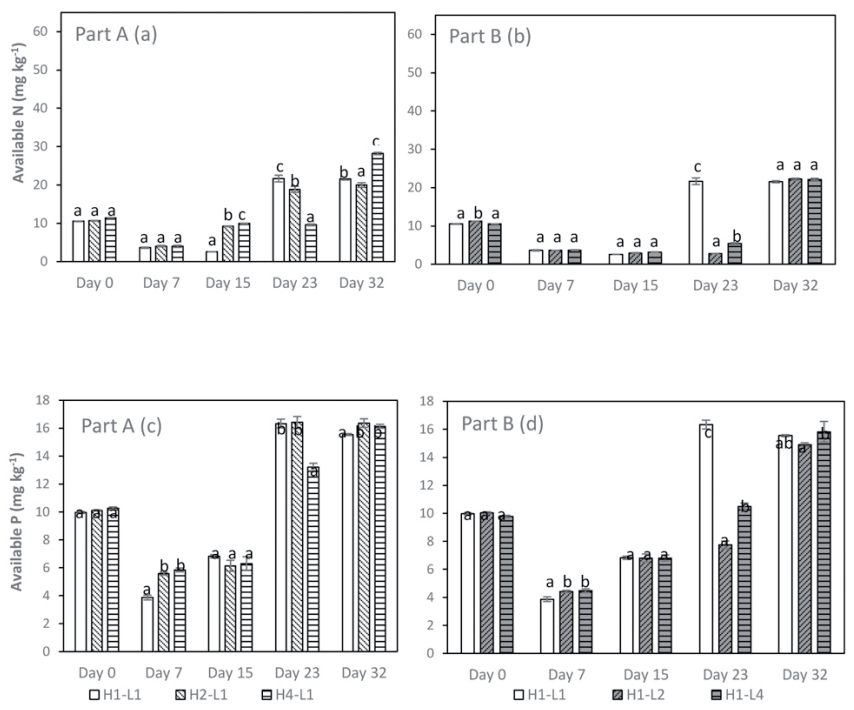

Figure 4. Available N (a) and available $\mathrm{P}(\mathrm{b})$ concentration on days $0,7,15,23,32$ in soil amended with high $\mathrm{C} / \mathrm{N}(\mathrm{H})$ and then low $\mathrm{C} / \mathrm{N}$ residue. Part A ( $\mathrm{a}, \mathrm{c}, \mathrm{e})$ different frequencies of $\mathrm{H}$ in first 15 days followed by single addition, and Part $\mathrm{B}$ (b, d, f) single $\mathrm{H}$ addition in first 15 days followed by different frequencies of $\mathrm{L}(\mathrm{n}=4)$. For each sampling date, different letters indicate significant differences $(\mathrm{P} \leq 0.05)$. For treatment structure, see Table 2.

\subsection{Single $H$ addition in the first 16 days followed by} $L$ added once, twice or four times (Part B)

After addition of $\mathrm{H}$ on $\mathrm{d} 0$, respiration rate increased in the first four days and then slowly decreased (Figure $1 \mathrm{~b}$ ). Addition of $\mathrm{L}$ on $\mathrm{d} 16$ resulted in an up to 10 fold increase in respiration rate on $\mathrm{d} 17$. Respiration rates on $\mathrm{d} 17$ increased with $\mathrm{L}$ addition rate (H1-L1 $>\mathrm{H} 1-\mathrm{L} 2>\mathrm{H} 1-\mathrm{L} 4)$. At the same $\mathrm{L}$ addition rate
(L1, L2 or L4), respiration rate on $\mathrm{d} 17$ was about $20 \%$ higher than on d1. Further $\mathrm{L}$ additions resulted in a transient increase in respiration rate with higher peak respiration rates than the first $\mathrm{L}$ addition on $\mathrm{d} 15$.

Cumulative respiration from $\mathrm{d} 1 \mathrm{to} \mathrm{d} 7$ was about twofold higher than from $\mathrm{d} 8$ to $\mathrm{d} 15$; it did not differ among treatments in the first two weeks (Figure 2b). After addition of $\mathrm{L}$ on $\mathrm{d} 16$, cumulative respiration from $\mathrm{d} 16$ to $\mathrm{d} 23$ was four to five-fold higher compared to $\mathrm{d} 8$ to 
to d15, with a greater increase in H1-L1 than H1-L2 and H1-L4. Cumulative respiration from $\mathrm{d} 16$ to $\mathrm{d} 23$ was about 30\% higher in H1-L1 than H1-L2 and H1L4. Compared to $\mathrm{d} 16$ to $\mathrm{d} 23$, cumulative respiration from d 24 to $\mathrm{d} 32$ was $60 \%$ lower in $\mathrm{H} 1-\mathrm{L} 1$, whereas it was about $20 \%$ higher in H2-L1 and H4-L1. Consequently, cumulative respiration from $\mathrm{d} 24$ to $\mathrm{d} 32$ was more than two-fold higher in H1-L2 and H1-L4 than in H1-L1.

Microbial biomass $\mathrm{C}$ on $\mathrm{d} 7$ and $\mathrm{d} 15$ did not differ among treatments, but was about four times lower on d15 than on $\mathrm{d} 7$ (Figure 3b). Compared to d15, MBC was about seven-fold higher on $\mathrm{d} 23$ in all treatments. Microbial biomass $\mathrm{C}$ did not change from $\mathrm{d} 23$ to $\mathrm{d} 32$ in H1-L2 and H1-L4, but halved in H1-L1. On d32, MBC was two-fold higher in H1-L2 and H1-L4 than H1-L1.

Microbial biomass $\mathrm{N}$ was up to three times higher on $\mathrm{d} 7$ than $\mathrm{d} 15$ (Figure $3 \mathrm{~d}$ ). Addition of $\mathrm{L}$ on d16 resulted in a nearly ten-fold increase in MBN on d23 compared to d15. This increase was greatest in H1L4 and smallest in H1-L1. Microbial biomass N was about $50 \%$ lower on $\mathrm{d} 32$ than $\mathrm{d} 23$, but remained lower in H1-L1 than H1-L2 and H1-L4.

Microbial biomass $\mathrm{P}$ changed little between $\mathrm{d} 7$ and d15 and did not differ among treatments (Figure 3f). On d23, MBP in was four-fold higher than d15 in all treatments. Microbial biomass P decreased from d23 to $\mathrm{d} 32$ with a greater decrease in H1-L1 than H1-L2 and H1-L4. On d32, MBP was about two-fold higher in H1-L2 and H1-L4 than H1-L1.

Available $\mathrm{N}$ did not differ among treatments on $\mathrm{d} 0$, $\mathrm{d} 7$ and $\mathrm{d} 15$, and was about three-fold higher on $\mathrm{d} 0$ than $\mathrm{d} 7$ and $\mathrm{d} 15$ (Figure 4b). Available $\mathrm{N}$ increased five-fold from d15 to d23 in H1-L1, but increased very little in H1-L2 and H1-L4. On d23, available N was about five-fold higher in H1-L1 than the other two treatments. From d23 to d32, available N did not change in H1-L1, but increased about five-fold in H1-
L2 and H1-L4 so that there was no difference among $\mathrm{H}-\mathrm{L}$ treatments on $\mathrm{d} 32$.

Available $\mathrm{P}$ on $\mathrm{d} 0, \mathrm{~d} 7$ and $\mathrm{d} 15$ was similar among treatments; it was highest on d0 (Figure 4d). Compared to d15, available P on $\mathrm{d} 23$ was more than twofold higher in H1-L1, but changed little in the other two $\mathrm{H}-\mathrm{L}$ treatments. It was about $50 \%$ lower in H1-L2 and H1-L4 than H1-L1. Available P increased about two-fold from d23 to d32 in H1-L2 and H1-L4, but remained unchanged in H1-L1. Thus available P was similar among treatments on $\mathrm{d} 32$.

\section{Discussion}

Residue addition frequency influenced soil respiration, microbial biomass and nutrient availability both in the first and second period. Further, residue addition frequency influenced the legacy effect, i.e. to what extent the high $\mathrm{C} / \mathrm{N}$ residue added in the first period affected soil respiration, microbial biomass and nutrient availability after addition of low $\mathrm{C} / \mathrm{N}$ residue.

\subsection{Addition frequency of $H$ in the first 15 days}

In the first seven days (d1-7), cumulative respiration was about $30 \%$ higher with a single addition (H1) compared to residue added twice or four times $(\mathrm{H} 2, \mathrm{H} 4)$ which can be explained by the smaller amount of residue added in the latter. Microbial biomass and nutrient availability on $\mathrm{d} 7$ were not influenced by addition rate because of the low $\mathrm{N}$ and $\mathrm{P}$ concentration in $\mathrm{H}$ residues. The lower cumulative respiration per $\mathrm{g} \mathrm{C}$ added with a single addition compared to residue added twice or four times is in agreement with Duong et al. (2009). It is likely that with the large amount of residue with a single addition $\left(10 \mathrm{~g} \mathrm{~kg}^{-1}\right)$, residue particles formed clumps which would reduce accessibility to microbes compared to the more uniform distribution of residues 
added in smaller amounts more frequently (2.5 or $5 \mathrm{~g} \mathrm{~kg}^{-1}$ ).

In the second week (d8-15) cumulative respiration was lower than in the first week with a single addition, whereas it was higher when residue was added twice or four times. With a single addition, easily decomposable compounds are rapidly decomposed initially as indicated by high respiration rates (e.g., Hadas et al. 2004). Upon depletion of these compounds, respiration rates decline. Similarly, MBC, MBN and MBP decreased from d7 to d15. The higher cumulative respiration in the second week when residue was added twice or four times compared to the single addition can be explained by addition of easily decomposable compounds in these treatments. Residue addition frequency had little effect on MBC, MBN and MBP or available $\mathrm{N}$ and $\mathrm{P}$ on $\mathrm{d} 15$ probably because by then, even when residue was added four times (last addition on day 12) easily decomposable compounds were depleted. Nevertheless, it is likely that a greater proportion of the microbial biomass was active on $\mathrm{d} 15$ when they had received residue seven (H2) or three days (H4) before than when residue was added 15 days ago (H1). This greater level of activity is evident in the higher respiration rates from d10 to d16 with residues added twice of four times compared to a single addition. Thus, the first hypothesis (frequent residue addition compared to a single addition will result in smaller residue effect on respiration, microbial biomass and nutrient availability initially, but later these parameters will be higher) can be confirmed.

\subsection{Effect of $H$ addition frequency after single $L$ ad- dition (Part A)}

The second hypothesis (the legacy effect of the previous residue will be greater when it is added frequently compared to a single addition) can be confirmed.
Previously we showed that respiration, MBC, MBN and MBP, available $\mathrm{N}$ and $\mathrm{P}$ are higher with $\mathrm{L}$ than $\mathrm{H}$ (e.g., Zheng and Marschner 2017). After addition of $\mathrm{L}$ to soil previously amended with $\mathrm{H}$, microbes will decompose $\mathrm{H}$ and $\mathrm{L}$ residues together. Therefore the stronger the legacy effect of the previous $\mathrm{H}$ addition, the lower respiration, $\mathrm{MBC}, \mathrm{MBN}$ and MBP, available $\mathrm{N}$ and $\mathrm{P}$ will be. Cumulative respiration between $\mathrm{d} 16$ and $\mathrm{d} 32$ was lower in H1-L1 than H2-L1 and H4L1 with more marked differences between d16 and d23 than later. This, together with the higher respiration rate before $\mathrm{d} 16$, indicates that microbes on $\mathrm{d} 16$ more active if residues had been added four (H4-L1) or eight days (H2-L1) before compared to 16 days before (H1-L1). The greater activity is also reflected in higher $\mathrm{MBC}, \mathrm{MBN}$ and $\mathrm{MBP}$ on $\mathrm{d} 23$ in $\mathrm{H} 2-\mathrm{L} 1$ and H4-L1 than H1-L1. Greater N and P uptake by the microbial biomass can explain the lower $\mathrm{N}$ and $P$ availability on $\mathrm{d} 23$ in H4-L1 than H1-L1. The greater microbial nutrient uptake in H2-L1 and H4L1 suggests preferential decomposition of freshly added $\mathrm{L}$ by the more active microbes compared to H1-L1. Increased decomposition of newly added organic substrate after repeated addition was reported by Cavalli et al. (2014) where repeated slurry application increased decomposition of the slurry while decreasing SOC mineralisation.

The decrease in MBC, MBN and MBP and respiration rate from $\mathrm{d} 23$ to $\mathrm{d} 32$ indicates depletion of easily decomposable compounds. Microbial turnover, that is decrease in MBN and MBP, can explain the increase in available $\mathrm{N}$ and $\mathrm{P}$ from $\mathrm{d} 23$ to $\mathrm{d} 32$. Nevertheless, MBC, MBN and MBP remained lower in H1-L1 than in H2-L1 and H4-L1, suggesting that the previous $\mathrm{H}$ addition rate influenced microbial utilisation of L more than two weeks after the last addition of $\mathrm{H}$. Addition frequency of $\mathrm{H}$ had little effect on available $\mathrm{P}$, likely because of $\mathrm{P}$ buffering by the soil (Nye 1966). 


\subsection{Single $H$ addition followed by different frequency of $L$ (Part B)}

Similar as with different $\mathrm{H}$ addition frequency in the first 16 days, cumulative respiration in the first week after $\mathrm{L}$ addition (d16 to $\mathrm{d} 23$ ) was higher in H1-L1 than H1-L2 and H1-L4, but in the following week (d24 to d32) it was lower in H1-L1 than the other two treatments. This can be explained by the addition of easily decomposable compounds in H1-L2 and H1-L4 which would be depleted by the second week in H1-L1 where $\mathrm{L}$ was added on $\mathrm{d} 16$.

The third hypothesis (the legacy effect of a previous single addition will be be smaller when the following residue is added frequently compared to a single addition) can be confirmed. On d23, only MBN was lower in H1-L1 than H1-L2 and H1-L4, but on d32, MBC, MBN and MBP were lower in H1-L1 that the other two treatments. This suggests that when $\mathrm{L}$ had been added at least twice (d16 and d24 in H1-L2 and d16, d20, d24, and d28in H1-L4), microbes will mineralise predominantly $\mathrm{L}$ residues whereas the $\mathrm{H}$ residue left from the first 15 days is little decomposed.

The effect on $\mathrm{L}$ addition frequency on $\mathrm{N}$ and $\mathrm{P}$ availability on $\mathrm{d} 23$ and $\mathrm{d} 32$ differed from that on microbial biomass. Availability of $\mathrm{N}$ and $\mathrm{P}$ on $\mathrm{d} 23$ was higher in H1-L1 than in H1-L2 and H1-L4 which can be explained by the lower MBN in H1-L1. The increase in N and $\mathrm{P}$ availability from $\mathrm{d} 23$ to $\mathrm{d} 32$ in H1-L2 and H1-L4 is likely due to microbial biomass turnover as indicated by the lower MBN and MBP on d32 than d23.

Residue addition frequency did not influence $\mathrm{N}$ and $\mathrm{P}$ availability on $\mathrm{d} 32$ probably because by then easily available compounds had been depleted in all treatments. Disappearance of the legacy effect of the previous residue on nutrient availability with time is in agreement with our previous studies (Marschner et al. 2015, Nguyen et al. 2016).

\section{Conclusion}

It can be concluded that the frequency at which the first residue was added influences its legacy effect after addition of the second residue. When the first residue was added two or four times, microbes are more active when the second residue is applied than with a single previous addition resulting in higher respiration and microbial nutrient uptake although $\mathrm{N}$ and $\mathrm{P}$ availability may be low. The effect of addition frequency of $\mathrm{L}$ in the second period after a single $\mathrm{H}$ addition on the measured parameters was different for microbial biomass than nutrient availability. More frequent $\mathrm{L}$ addition enhanced microbial nutrient uptake while reducing nutrient availability. However, this effect is limited to the first week after the second residue is added. To maximise nutrient availability for a crop sown immediately after incorporation of low $\mathrm{C} / \mathrm{N}$ residue following the harvest of a high $\mathrm{C} / \mathrm{N}$ plant (e.g. cereal), the low $\mathrm{C} / \mathrm{N}$ residue should be added once at a high rate. However, if sustained nutrient availability (uptake and then release of nutrients from the microbial biomass) is to be achieved, the first or the second residue should be added frequently. In the field, frequent residue addition may occur while plants are growing due to root turnover whereas a single residue addition mimics the situation where after harvest, residues are incorporated in the soil. To further elucidate mechanisms underlying the effect of residue addition frequency and the legacy effect, ${ }^{13} \mathrm{C}$ and ${ }^{15} \mathrm{~N}$ labelled residues could be used.

\section{References}

Anderson, J., Ingram, J. 1993. Colorimetric determination of ammonium. Tropical Soil Biology and Fertility, A Handbook of Methods, second ed. CAB International, Wallingford, UK, 73-74. 
Butterly, C.R., Marschner, P., McNeill, A.M., Baldock, J.A. 2010. Rewetting $\mathrm{CO}_{2}$ pulses in Australian agricultural soils and the influence of soil properties. Biol. Fertil. Soils 46, 739-753.

Cavagnaro, T.R., Jackson, L.E., Six, J., Ferris, H., Goyal, S., Asami, D., Scow, K.M. 2006. Arbuscular Mycorrhizas, Microbial Communities, Nutrient Availability, and Soil Aggregates in Organic Tomato Production. Plant Soil, 282, 209-225.

Cavalli, D., Bechini, L., Gallina, P.M. 2014. Measuring and Modeling Soil Carbon Respiration following Repeated Dairy Slurry Application. Soil Sci. Soc. Amer. J. 78, 1414-1425.

Chittleborough, D., Oades, J. 1979. The development of a red-brown earth. I. A reinterpretation of published data. Soil Res. 17, 371-381.

De Nobili, M., Contin, M., Mondini, C., Brookes, P.C. 2001. Soil microbial biomass is triggered into activity by trace amounts of substrate. Soil Biol. Biochem. 33, 1163-1170.

Duong, T.T.T., Baumann, K., Marschner, P. 2009. Frequent addition of wheat straw residues to soil enhances carbon mineralization rate. Soil Biol. Biochem. 41, 1475-1482.

Elmajdoub, B., Marschner, P. 2015. Responses of Soil Microbial Activity and Biomass to Salinity After Repeated Additions of Plant Residues. Pedosphere 25, 177-185.

Gee, G., Or, D. 2002. Particle size analysis. In 'Methods of soil analysis. Part 4. Physical methods'. (Eds JH Dane, GC Topp) pp. 255-294. Soil Science Society of America: Madison WI.

Hadas, A., Kautsky, L., Goek, M., Kara, E.E. 2004. Rates of decomposition of plant residues and available nitrogen in soil, related to residue composition through simulation of carbon and nitrogen turnover. Soil Biol. Biochem. 36, 255-266.
Hanson, W. 1950. The photometric determination of phosphorus in fertilizers using the phosphovanadomolybdate complex. J. Sci. Food Agricult. 1, 172-173.

Isbell, R. 2002. The Australian Soil Classification, Revised edn (CSIRO Publishing, Collingwood, Vic.).

Kouno, K., Tuchiya, Y., Ando, T. 1995. Measurement of soil microbial biomass phosphorus by an anion exchange membrane method. Soil Biol. Biochem. 27, 1353-1357.

Marschner, P., Hatam, Z., Cavagnaro, T. 2015. Soil respiration, microbial biomass and nutrient availability after the second amendment are influenced by legacy effects of prior residue addition. Soil Biol. Biochem. 88, 169-177.

Moore, J., Klose, S., Tabatabai, M. 2000. Soil microbial biomass carbon and nitrogen as affected by cropping systems. Biol. Fertil. Soils. 31, 200-210.

Murphy, J., Riley, J.P. 1962. A modified single solution method for the determination of phosphate in natural waters. Anal. Chim. Acta. 27, 31-36.

Nguyen, T.T., Cavagnaro, T.R., Ngo, H.T.T., Marschner, P. 2016a. Soil respiration, microbial biomass and nutrient availability in soil amended with high and low $\mathrm{C} / \mathrm{N}$ residue - Influence of interval between residue additions. Soil Biol. Biochem. 95, 189-197.

Nguyen, T.T., Ngo, H.T.T., Marschner, P. 2016b. Legacy effect of previous residue addition - influence of length of the moist period between residue additions on soil respiration, microbial biomass and nutrient availability. Biol. Fertil. Soils. 1-11.

Pal, S., Marschner, P. 2016. Influence of clay concentration, residue $\mathrm{C} / \mathrm{N}$ and particle size on microbial activity and nutrient availability in clay-amended sandy soil. J. Soil Sci. Plant Nutrit. 16, 350-361. 
Rayment, G., Higginson, F.R. 1992. Australian laboratory handbook of soil and water chemical methods. Inkata Press Pty Ltd.

Scotti, R., Bonanomi, G., Scelza, R., Zoina, A., Rao, M.A. 2015. Organic amendments as sustainable tool to recovery fertility in intensive agricultural systems. J. Soil Sci. Plant Nutri. 15, 333-352.

Setia, R., Marschner, P., Baldock, J., Chittleborough, D., Verma, V. 2011. Relationships between carbon dioxide emission and soil properties in salt-affected landscapes. Soil Biol. Biochem. 43, 667-674.

Tian, G., Kang, B., Brussaard, L. 1992. Biological effects of plant residues with contrasting chemical compositions under humid tropical conditionsdecomposition and nutrient release. Soil Biol. Biochem. 24, 1051-1060.

Vance, E.D., Brookes, P.C., Jenkinson, D.S. 1987. An extraction method for measuring soil microbial biomass C. Soil Biol. Biochem. 19, 703-707.
Vanlauwe, B., Nwoke, O., Sanginga, N., Merckx, R. 1996. Impact of residue quality on the $\mathrm{C}$ and $\mathrm{N}$ mineralization of leaf and root residues of three agroforestry species. Plant Soil 183, 221-231.

Walkley, A., Black, I.A. 1934. An examination of the Degtjareff method for determining soil organic matter, and a proposed modification of the chromic acid titration method. Soil Sci. 37, 29-38.

Wilke, B.-M. 2005. Determination of chemical and physical soil properties, Monitoring and Assessing Soil Bioremediation. Springer, pp. 47-95.

Willis, R.B., Montgomery, M.E., Allen, P.R. 1996. Improved Method for Manual, Colorimetric Determination of Total Kjeldahl Nitrogen Using Salicylate. J. Agricult. Food Chem. 44, 1804-1807.

Zheng, B., Marschner, P. 2017. Previous residue addition rate and $\mathrm{C} / \mathrm{N}$ ratio influence nutrient availability and respiration rate after the second residue addition. Geoderma. 285, 217-224. 